\title{
Zinc Requirements of Tropical Legume Cover Crops
}

\author{
Nand K. Fageria1, Virupax C. Baligar², Marshall K. Elson² \\ ${ }^{1}$ National Rice and Bean Research Center of EMBRAPA (Empresa Brasileira de Pesquisa Agropecuária), Santo \\ Antônio de Goiás, Brazil \\ ${ }^{2}$ Beltsville Agricultural Research Center, USDA-ARS, Beltsville, USA \\ Email: Nand.fageria@embrapa.br
}

Received 8 April 2014; revised 7 May 2014; accepted 21 May 2014

Copyright (C) 2014 by authors and Scientific Research Publishing Inc.

This work is licensed under the Creative Commons Attribution International License (CC BY). http://creativecommons.org/licenses/by/4.0/

(c) $\underset{\mathrm{EY}}{\mathrm{i}}$ Open Access

\section{Abstract}

Tropical soils are deficient in essential plant nutrients, including zinc (Zn). Using cover crops in cropping systems is an important option to improve soil fertility for sustainable crop production. However, success of cover crops in highly weathered tropical infertile acid soils is greatly influenced by adequate levels of available soil micronutrients. A greenhouse experiment was conducted to evaluate the $\mathrm{Zn}$ requirements of ten major tropical legume cover crops. The $\mathrm{Zn}$ levels used were 0 , 10,20 and $40 \mathrm{mg} \cdot \mathrm{kg}^{-1}$ soil. Overall, shoot and root dry weight and maximum root length increased significantly in a quadratic fashion with increasing $\mathrm{Zn}$ rates in the range of 0 to $40 \mathrm{mg} \cdot \mathrm{kg}^{-1}$. The $\mathrm{Zn}$ $x$ cover crops interactions for shoot and root dry weight, maximum root length, Zn concentration (content per unit dry weight), $\mathrm{Zn}$ uptake (concentration $\times$ dry weight) and $\mathrm{Zn}$ use efficiency (dry weight per unit $\mathrm{Zn}$ uptake) were significant, indicating variation in these traits with the change in soil Zn levels. Collectively, maximum shoot dry weight was achieved with the application of $22 \mathrm{mg}$ $\mathrm{Zn} \cdot \mathrm{kg}^{-1}$ of soil. Similarly, maximum root dry weight and root length were obtained with the addition of 22 and $17 \mathrm{mg} \mathrm{Zn} \cdot \mathrm{kg}^{-1}$ soil, respectively. Overall, $\mathrm{Zn}$ concentration and $\mathrm{Zn}$ uptake were significantly increased in a quadratic manner with the increase in the soil $\mathrm{Zn}$ levels in the range of 0 to $40 \mathrm{mg} \cdot \mathrm{kg}^{-1}$. However, $\mathrm{Zn}$ use efficiency (dry weight per unit $\mathrm{Zn}$ uptake) decreased in a quadratic fashion with the increasing soil $\mathrm{Zn}$ levels from 0 to $40 \mathrm{mg} \cdot \mathrm{kg}^{-1}$. Jack bean, black velvet bean, pueraria, and gray velvet bean with high $\mathrm{Zn}$ use efficiency appear to be suitable cover crops for low $\mathrm{Zn}$ soils.

\section{Keywords}

Root and Shoot Dry Weight, Root Length, Zn Use Efficiency

\section{Introduction}

Zinc (Zn) deficiency is a widespread nutrient disorder in crop plants worldwide [1] [2]. The deficiency of 
micronutrients, including Zn, in crop plants is related to several soil and plant factors. These factors are low natural levels of micronutrients in the soils, use of high yielding cultivars, liming of acid soils, interactions among macro and micronutrients, planting on sandy and calcareous soils, increased use of high analysis fertilizers containing low amounts of micronutrients, and decreased use of organic amendments such as animal manures, composts, and crop residues [1] [2]. Graham [3] reported that half of the world's soils are intrinsically deficient in Zn. Zinc deficiency in annual crops is reported in Brazil [4], Australia [3], India [5], China [6], Turkey [7], Europe[8], USA [9], and Africa [10].

In Brazil, Zn deficiency is very common in crop plants grown on Oxisols and Ultisols, which are acidic and have low concentrations of $\mathrm{Zn} \mathrm{[1]} \mathrm{[4]} \mathrm{[11].} \mathrm{In} \mathrm{addition,} \mathrm{these} \mathrm{soils} \mathrm{require} \mathrm{liming} \mathrm{to} \mathrm{reduce} \mathrm{soil} \mathrm{acidity,} \mathrm{improve}$ $\mathrm{Ca}$ and $\mathrm{Mg}$ contents and increase activities of beneficial microorganisms. Zn deficiency in these soils has been reported in upland rice, corn, sorghum, wheat, soybean and dry bean [12]. In addition to Zn, these soils are also deficient in N, P, Ca, Mg, S, B and Cu [1] [13] [14]. The strategies which can be adopted to improve micronutrients uptake by crop plants can be divided into two groups. In the first group, bioavailability of soil micronutrients can be improved by adopting practices such as use of adequate rate, proper sources and suitable methods of application. Fertilizer management practices (source, rate, placement, and application time) should be optimized based on soil, plant, and climatic factors to reduce mineral losses (leaching, runoff, fixation) and improve their availability [1]. Improvement and consideration of these factors will enhance recovery of added fertilizers [1]. Cakmak [7] also reported that agronomic biofortification is of great importance in enriching the seeds of food crops with $\mathrm{Zn}$. In the second group, use of crop species or genotypes within a species which are efficient in micronutrients uptake and translocation to the grain can improve Zn utilization efficiency [14] [15].

Cover crops are important components of cropping systems in improving soil fertility, controlling weeds, diseases and insects [16]. In addition, cover crops also help in conserving soil moisture, reducing soil erosion and improving soil microbiology [16] [17]. Information is limited on the response of cover crops to Zn fertilization in acidic, infertile tropical soils of South America. Cover crop species having high Zn efficiency might produce higher yields and persist longer when grown on infertile soils where the supply of $\mathrm{Zn}$ is limited [18] [19]. The objectives of this study were to evaluate the influence of soil $\mathrm{Zn}$ levels on shoot and root growth and nutrition and use efficiency of $\mathrm{Zn}$ in ten important tropical legume cover crops.

\section{Materials and Methods}

A greenhouse experiment was conducted to determine Zn requirements of ten tropical legume crops. The soil used in the experiment was an Oxisol whose chemical and physical properties were: $\mathrm{pH}$ 5.1, Ca $0.2 \mathrm{cmolc} \cdot \mathrm{kg}^{-1}$, Mg 0.2 cmolc $\cdot \mathrm{kg}^{-1}$, Al 0.1 cmolc $\cdot \mathrm{kg}^{-1}$, K $30 \mathrm{mg} \cdot \mathrm{kg}^{-1}$, P $0.3 \mathrm{mg} \cdot \mathrm{kg}^{-1}$, Zn $0.2 \mathrm{mg} \cdot \mathrm{kg}^{-1}$, Cu $1.6 \mathrm{mg} \cdot \mathrm{kg}^{-1}$, Fe 30 $\mathrm{mg} \cdot \mathrm{kg}^{-1}, \mathrm{Mn} 7 \mathrm{mg} \cdot \mathrm{kg}^{-1}$, and organic matter $1.4 \mathrm{~g} \cdot \mathrm{kg}^{-1}$. Soil textural analysis was clay $594 \mathrm{~g} \cdot \mathrm{kg}^{-1}$, silt $147 \mathrm{~g} \cdot \mathrm{kg}^{-1}$ and sand $258 \mathrm{~g} \cdot \mathrm{kg}^{-1}$. Soil analysis methods used in this study are described in a soil analysis manual published by EMBRAPA [20].

Cover crops used for the experiment are listed in Table 1. Zinc levels used were 0, 10, 20 and $40 \mathrm{mg} \mathrm{Zn \cdot \textrm {kg } ^ { - 1 }}$ of soil and applied as zinc sulfate (23\% Zn). Basic fertilizer rates used were $N 200 \mathrm{mg} \cdot \mathrm{kg}^{-1}$, P $200 \mathrm{mg} \cdot \mathrm{kg}^{-1}$ and $\mathrm{K} 200 \mathrm{mg} \cdot \mathrm{kg}^{-1}$. Nitrogen was applied as urea, $\mathrm{P}$ applied as triple superphosphate and $\mathrm{K}$ applied as potassium chloride. One g of dolomitic lime $\left(1 \mathrm{~g} \cdot \mathrm{kg}^{-1}\right.$ soil) was thoroughly mixed with the soil six weeks before sowing of the cover crop seeds. The experiment was conducted in plastic pots with $7 \mathrm{~kg}$ soil in each pot. The experimental design was a randomized block arranged in a split plot. Zinc levels were the main plots and cover crops were the sub-plots. Each experimental unit was replicated three times. After germination, four plants were maintained in each pot. Plants were harvested 50 days after sowing. After harvesting the shoots, roots were removed from the soil manually and washed in water and distilled water several times. Maximum root length was measured. Plant materials were dried in a forced draft oven at $70^{\circ} \mathrm{C}$ to a constant weight to determine the dry weight of shoots and roots. Plant shoots were ground and analyzed for $\mathrm{Zn}$ according to the methods described by Silva [21].

Zinc use efficiency was calculated by using the following equation:

$$
\text { Zn use efficiency }\left(\mathrm{mg} \cdot \mu \mathrm{g}^{-1}\right)=\frac{\text { Dry weight in } \mathrm{mg}}{\text { Uptake of Zn in } \mu \mathrm{g}}
$$

SAS was used for Analysis of Variance and quadratic regression models were determined to describe the shoot dry weight, root dry weight and maximum root length responses to $\mathrm{Zn}$ application. Similar quadratic 
Table 1. Common and scientific names of ten legume cover crop species used in the experiment.

\begin{tabular}{ll}
\hline \multicolumn{1}{c}{ Common name } & \multicolumn{1}{c}{ Scientific name } \\
\hline 1. Sunn hemp & Crotalaria juncea L. \\
2. Smooth crotalaria & Crotalaria mucronata (C. pallida Aiton) \\
3. Showy Crotalaria & Crotalaria spectabilis Roth \\
4. Calopo & Calopogonium mucunoides Desv. \\
5. Pueraria (Tropical Kudzu) & Pueraria phaseoloides Roxb. \\
6. Pigeonpea (black) & Cajanus cajan L. Millspaugh \\
7. Lablab & Lablab purpureus (L.) Sweet (Dolichos Lablab) \\
8. Black velvet bean (Black mucuna bean) & Mucuna aterrima (Piper \& Tracy) Holland (M. pruriens, L. DC.) \\
9. Gray velvet bean (Gray mucuna bean) & Mucuna cinereum L. \\
10. Jack bean & Canavalia ensiformis L. DC. \\
\hline
\end{tabular}

regression models were used to describe $\mathrm{Zn}$ rate versus $\mathrm{Zn}$ concentration, Zn uptake and Zn use efficiency in the plants. Similarly, the relationship between soil chemical properties and shoot dry weight was determined by quadratic regression model to calculate values of soil chemical properties for maximum dry weight. The quadratic model is a second order polynomial function written as:

$$
\mathrm{Y}=\mathrm{a}+\mathrm{bX}+\mathrm{cX} \mathrm{X}^{2}
$$

where $\mathrm{Y}=$ the estimated yield, $\mathrm{X}=$ application rate of $\mathrm{Zn}$. The a, b, c, are coefficients estimated by fitting the model to the data. The quadratic function assumes that cover crop shoot dry weight, root dry weight and maximum root length, $\mathrm{Zn}$ concentration and uptake in the plant tissues will increase at a decreasing rate as the $\mathrm{Zn}$ application rate increases until the maximum yield is achieved at a determined $\mathrm{Zn}$ rate.

\section{Results and Discussion}

\subsection{Shoot Dry Weight}

The shoot dry weight of the ten cover crops was significantly influenced by Zn level, cover crop treatments and $\mathrm{Zn} \times$ cover crops interaction (Table 2 ). The significant interaction between $\mathrm{Zn} \times$ cover crops indicates variation in dry weight of shoots of cover crops with the variation in soil $\mathrm{Zn}$ rates. At the $0 \mathrm{mg} \mathrm{Zn} \cdot \mathrm{kg}^{-1}$ soil rate, shoot dry weight varied from $0.38 \mathrm{~g} \cdot$ plant $^{-1}$ produced by calopo to $7.95 \mathrm{~g} \cdot$ plant $^{-1}$ produced by jack bean, with an average

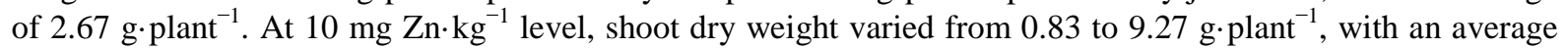
value of $4.01 \mathrm{~g} \cdot$ plant $^{-1}$. At $20 \mathrm{mg} \cdot \mathrm{kg}^{-1} \mathrm{Zn}$ level, dry weight of shoots varied from 0.79 to $9.98 \mathrm{~g} \cdot \mathrm{plant}^{-1}$, with an average value of $3.99 \mathrm{~g} \cdot$ plant $^{-1}$. At the maximum $\mathrm{Zn}$ level $\left(40 \mathrm{mg} \cdot \mathrm{kg}^{-1}\right)$, shoot dry weight varied from 0.70 to $9.31 \mathrm{~g} \cdot$ plant $^{-1}$ with an average value of $9.31 \mathrm{~g} \cdot$ plant $^{-1}$. However shoot dry weight of all the cover crops decreased at this level of Zn application. Across all four Zn levels, minimum dry weight of $0.73 \mathrm{~g} \cdot$ plant $^{-1}$ was $^{-1}$ produced by pueraria and maximum dry weight of $9.13 \mathrm{~g} \cdot$ plant $^{-1}$ was produced by jack bean, with an average value of $3.45 \mathrm{~g} \cdot$ plant $^{-1}$. Significant variation in shoot dry weight among cover crops has been reported by Fageria et al. [22]. Low fertility is a major constraint for good growth of legume cover crops in tropical plantation crops [22]. Similarly, Baligar and Fageria [16] reported that growth of cover crops is determined genetically and is affected by environmental variables including fertilizers.

The increase in shoot dry weight fit quadratic curves with increasing $\mathrm{Zn}$ levels in the range of 0 to $40 \mathrm{mg} \cdot \mathrm{kg}^{-1}$ (Table 3). The maximum shoot dry weight was obtained with the application of $16 \mathrm{mg} \mathrm{Zn} \cdot \mathrm{kg}^{-1}$ soil for showy crotalaria to $32 \mathrm{mg} \mathrm{Zn} \cdot \mathrm{kg}^{-1}$ for calopo. The maximum shoot dry weight of the ten cover crops averaged together

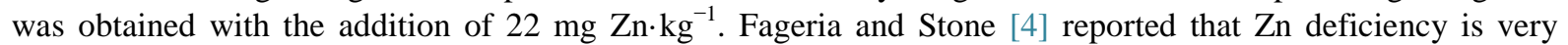
common in crops grown on Brazilian Oxisols. Fageria et al. [1] reported that Zn deficiency in highly weathered Oxisols and Ultisols is due to low levels of this element in the parent materials. In addition, Fageria [14] reported that liming is an essential and dominant practice to improve yields of crops on highly weathered acid 
Table 2. Influence of soil $\mathrm{Zn}$ on shoot dry weight $\left(\mathrm{g} \cdot\right.$ plant $^{-1}$ ) of ten tropical legume cover crops.

\begin{tabular}{|c|c|c|c|c|c|}
\hline \multirow{2}{*}{ Cover crops } & \multicolumn{4}{|c|}{ Zinc levels $\left(\mathrm{mg} \cdot \mathrm{kg}^{-1}\right)$} & \multirow{2}{*}{ Average } \\
\hline & 0 & 10 & 20 & 40 & \\
\hline 1. Sunn hemp & $3.01 \mathrm{c}$ & 3.38d & $2.54 \mathrm{~d}$ & $2.75 c$ & 2.92d \\
\hline 2. Smooth crotalaria & $0.66 \mathrm{de}$ & 1.07ef & 1.13ef & $0.70 \mathrm{e}$ & $0.89 f g$ \\
\hline 3. Showy crotalaria & 1.08de & $1.24 \mathrm{ef}$ & $1.23 \mathrm{ef}$ & $0.96 \mathrm{de}$ & $1.13 \mathrm{f}$ \\
\hline 4. Calopo & $0.38 \mathrm{e}$ & $0.83 \mathrm{f}$ & $0.79 \mathrm{f}$ & 0.94de & $0.74 \mathrm{~g}$ \\
\hline 5. Pueraria & $0.57 \mathrm{de}$ & $0.78 \mathrm{f}$ & $0.83 \mathrm{f}$ & $0.74 \mathrm{e}$ & $0.73 \mathrm{~g}$ \\
\hline 6. Pigeonpea & $1.18 \mathrm{~d}$ & $1.60 \mathrm{e}$ & 2.04de & $2.03 c$ & $1.71 \mathrm{e}$ \\
\hline 7. Lablab & $3.46 \mathrm{c}$ & $7.73 b$ & $7.96 \mathrm{~b}$ & $5.69 \mathrm{~b}$ & $6.21 \mathrm{~b}$ \\
\hline 8. Black velvet bean & $5.35 b$ & $6.49 \mathrm{c}$ & $7.55 b$ & $6.61 \mathrm{~b}$ & $6.50 \mathrm{~b}$ \\
\hline 9. Gray velvet bean & $3.03 \mathrm{c}$ & $7.67 \mathrm{~b}$ & $5.83 c$ & $1.85 \mathrm{~cd}$ & $4.59 \mathrm{c}$ \\
\hline 10. Jack bean & $7.95 a$ & $9.27 \mathrm{a}$ & $9.98 \mathrm{a}$ & 9.31a & 9.13a \\
\hline Average & $2.67 \mathrm{c}$ & $4.01 \mathrm{a}$ & 3.99a & $3.16 b$ & 3.45 \\
\hline \multicolumn{6}{|l|}{ F-Test } \\
\hline Zn levels (Zn) & & & & & $* *$ \\
\hline Cover crops (C) & & & & & $* *$ \\
\hline $\mathrm{Zn} \times \mathrm{C}$ & & & & & $* *$ \\
\hline CV Zn (\%) & & & & & 9.53 \\
\hline CV C (\%) & & & & & 8.30 \\
\hline
\end{tabular}

${ }^{* *}$ Significant at the $1 \%$ probability level. Means followed by the same letter in the same column are not statistically significant at the $5 \%$ probability level by Tukeys test. Average values were compared in the same line.

Table 3. Relationship between Zn rate and shoot dry weight (SDW) of ten tropical legume cover crops.

\begin{tabular}{llll}
\hline \multicolumn{1}{c}{ Variable } & \multicolumn{1}{c}{ Regression equation } & $\mathrm{R}^{2}$ & ZnRMTDW $^{1}$ \\
\hline 1. Zn rate vs SDW of Sunn hemp & $\mathrm{Y}=3.16-0.020 \mathrm{X}+0.00022 \mathrm{X}^{2}$ & $0.16^{\mathrm{NS}}$ & - \\
2. Zn rate vs SDW of smooth crotalaria & $\mathrm{Y}=0.67+0.048 \mathrm{X}-0.0012 \mathrm{X}^{2}$ & $0.86^{* *}$ & 16 \\
3. Zn rate vs SDW of showy crotalaria & $\mathrm{Y}=1.09+0.019 \mathrm{X}-0.00056 \mathrm{X}^{2}$ & $0.80^{* *}$ & 32 \\
4. Zn rate vs SDW of calopo & $\mathrm{Y}=0.43+0.033 \mathrm{X}-0.00051 \mathrm{X}^{2}$ & $0.73^{* *}$ & 24 \\
5. Zn rate vs SDW of pueraria & $\mathrm{Y}=0.58+0.023 \mathrm{X}-0.00047 \mathrm{X}^{2}$ & $0.66^{* *}$ & 31 \\
6. Zn rate vs SDW of pigonpea & $\mathrm{Y}=1.16+0.061 \mathrm{X}-0.00097 \mathrm{X}^{2}$ & $0.74^{* *}$ & 23 \\
7. Zn rate vs SDW of lablab & $\mathrm{Y}=3.71+0.429 \mathrm{X}-0.0095 \mathrm{X}^{2}$ & $0.91^{* *}$ & 25 \\
8. Zn rate vs SDW of black velvet bean & $\mathrm{Y}=5.27+0.179 \mathrm{X}-0.0036 \mathrm{X}^{2}$ & $0.81^{* *}$ & 18 \\
9. Zn rate vs SDW of gray velvet bean & $\mathrm{Y}=3.55+0.379 \mathrm{X}-0.0106 \mathrm{X}^{2}$ & $0.83^{* *}$ & 25 \\
10. Zn rate vs SDW of jack bean & $\mathrm{Y}=7.94+0.169 \mathrm{X}-0.0034 \mathrm{X}^{2}$ & $0.83^{* *}$ & 22 \\
Average of 10 cover crops & $\mathrm{Y}=2.75+0.132 \mathrm{X}-0.0031 \mathrm{X}^{2}$ & $0.90^{* *}$ & 25 \\
\hline
\end{tabular}

\footnotetext{
${ }^{* *, N S}$ Significant at the $1 \%$ probability level and not significant, respectively. ${ }^{1}$ ZnRMTDW $=\mathrm{Zn}$ rate for maximum tops dry weight in $\mathrm{mg} \cdot \mathrm{kg}^{-1}$ soil.
} 
soils. However, liming may induce Zn deficiency due to adsorption of this element on soil colloids by increasing soil pH [23]. Alloway [2] reported that Zn deficiency is by far the most ubiquitous micronutrient deficiency problem in the world. All crops can be affected by Zn deficiency but there is variation in Zn deficiency in crop species and genotypes within species [2]. Figure 1 shows growth of shoots of cover crops at different Zn levels. There was improvement in shoot growth with the addition of $\mathrm{Zn}$ and differences were evident among the cover crop species tested.

\subsection{Root Growth}

Root dry weight was significantly affected by $\mathrm{Zn}$ level, cover crop treatment and $\mathrm{Zn} \times$ cover crop interaction (Table 4). The $\mathrm{Zn} \times$ cover crop interaction indicates that there was variation in root dry weight among cover crops species with the variation in Zn levels. The root dry weight at the lowest $\mathrm{Zn}$ level $\left(0 \mathrm{mg} \mathrm{Zn} \cdot \mathrm{kg}^{-1}\right)$ varied

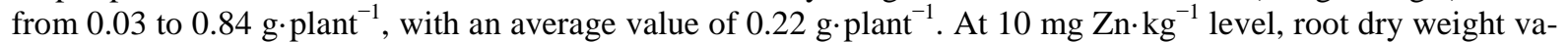
ried from 0.05 to $1.05 \mathrm{~g} \cdot \mathrm{plant}^{-1}$, with an average value of $0.36 \mathrm{~g} \cdot \mathrm{plant}^{-1}$. Similarly, at $20 \mathrm{mg} \mathrm{Zn} \cdot \mathrm{kg}^{-1}$ level, root dry weight varied from 0.03 to $0.93 \mathrm{~g} \cdot$ plant $^{-1}$, with an average value of $0.29 \mathrm{~g} \cdot$ plant $^{-1}$. At the highest $\mathrm{Zn}$ level (40 mg Zn $\mathrm{kg}^{-1}$ ), root dry weight varied from 0.03 to $0.80 \mathrm{~g} \cdot$ plant $^{-1}$, with an average value of $0.26 \mathrm{~g} \cdot$ plant $^{-1}$.

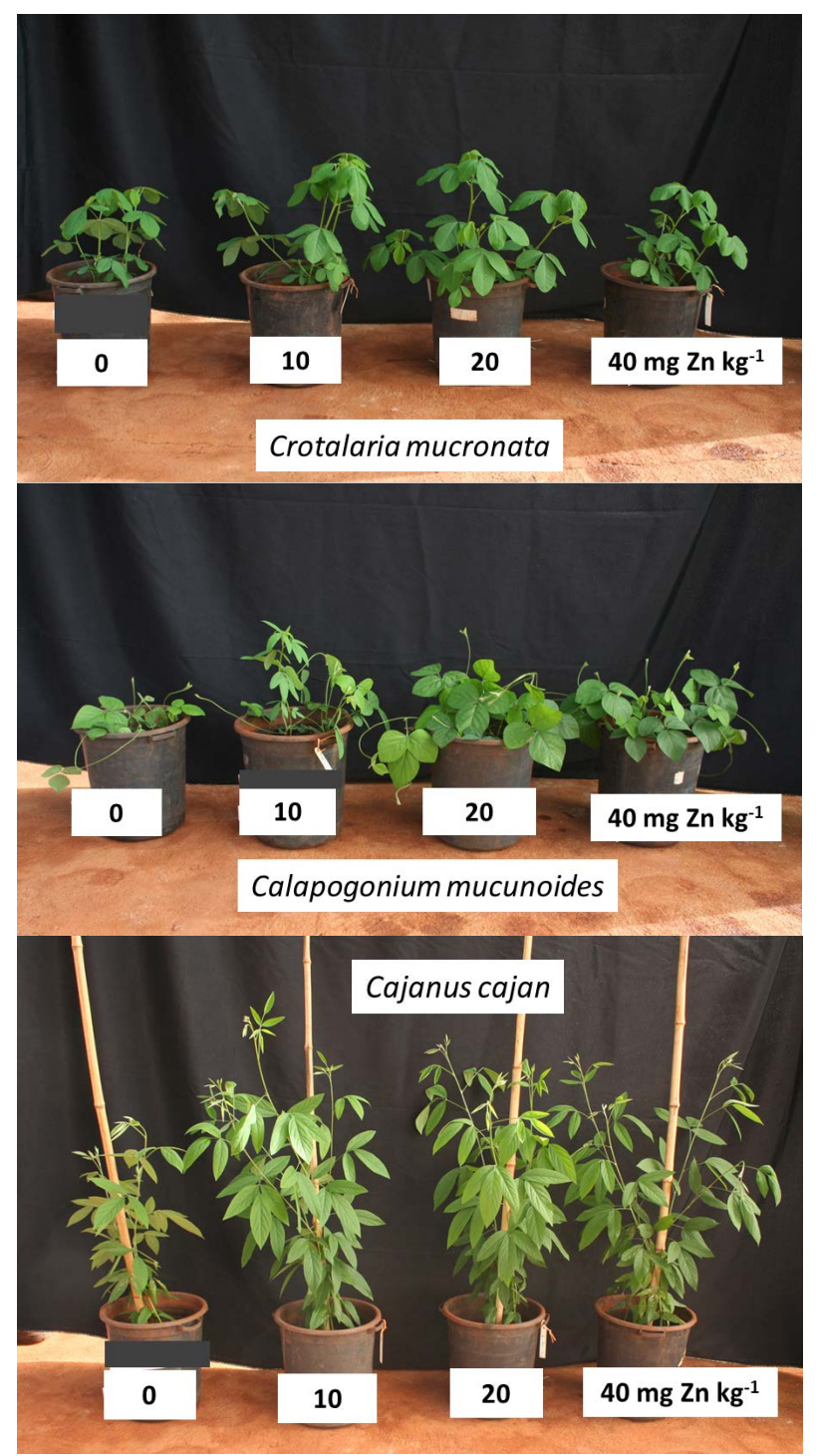

Figure 1. Growth of selected cover crops at different soil Zn levels. 
Table 4. Influence of soil $\mathrm{Zn}$ on root dry weight $\left(\mathrm{g} \cdot \mathrm{plant}^{-1}\right.$ ) of ten tropical legume cover crops.

\begin{tabular}{|c|c|c|c|c|c|}
\hline \multirow{2}{*}{ Cover crops } & \multicolumn{4}{|c|}{ Zinc levels (mg $\cdot \mathrm{kg}^{-1}$ ) } & \multirow{2}{*}{ Average } \\
\hline & 0 & 10 & 20 & 40 & \\
\hline 1. Sunn hemp & $0.06 \mathrm{c}$ & $0.22 \mathrm{de}$ & $0.04 \mathrm{~d}$ & $0.15 c$ & $0.12 \mathrm{~d}$ \\
\hline 2. Smooth crotalaria & $0.03 \mathrm{c}$ & $0.05 \mathrm{e}$ & $0.07 d$ & $0.03 c$ & $0.05 \mathrm{~d}$ \\
\hline 3. Showy crotalaria & $0.03 c$ & $0.08 \mathrm{e}$ & $0.03 \mathrm{~d}$ & $0.08 \mathrm{c}$ & $0.06 \mathrm{~d}$ \\
\hline 4. Calopo & $0.05 c$ & $0.09 \mathrm{e}$ & $0.03 \mathrm{~d}$ & $0.05 c$ & $0.06 \mathrm{~d}$ \\
\hline 5. Pueraria & $0.04 \mathrm{c}$ & $0.07 \mathrm{e}$ & $0.06 \mathrm{~d}$ & $0.03 c$ & $0.05 \mathrm{~d}$ \\
\hline 6. Pigeonpea & $0.03 c$ & $0.14 \mathrm{e}$ & $0.08 \mathrm{~d}$ & $0.07 \mathrm{c}$ & $0.08 \mathrm{~d}$ \\
\hline 7. Lablab & $0.36 \mathrm{~b}$ & $0.63 \mathrm{bc}$ & $0.58 b c$ & $0.54 \mathrm{~b}$ & $0.53 b$ \\
\hline 8. Black velvet bean & $0.84 a$ & $1.05 \mathrm{a}$ & $0.93 a$ & $0.80 \mathrm{a}$ & $0.90 \mathrm{a}$ \\
\hline 9. Gray velvet bean & $0.41 \mathrm{~b}$ & $0.82 \mathrm{ab}$ & $0.70 \mathrm{~b}$ & $0.43 b$ & $0.59 b$ \\
\hline 10. Jack bean & $0.36 b$ & $0.45 \mathrm{~cd}$ & $0.40 \mathrm{c}$ & $0.42 \mathrm{~b}$ & $0.41 \mathrm{c}$ \\
\hline Average & $0.22 \mathrm{c}$ & $0.36 \mathrm{a}$ & $0.29 \mathrm{~b}$ & $0.26 \mathrm{bc}$ & \\
\hline \multicolumn{6}{|l|}{ F-Test } \\
\hline Zn levels (Zn) & & & & & $* *$ \\
\hline Cover crops (C) & & & & & $* *$ \\
\hline $\mathrm{Zn} \times \mathrm{C}$ & & & & & $* *$ \\
\hline CV Zn (\%) & & & & & 26.83 \\
\hline CV C (\%) & & & & & 25.95 \\
\hline
\end{tabular}

${ }^{* *}$ Significant at the $1 \%$ probability level. Means followed by the same letter in the same column are not statistically significant at the $5 \%$ probability level by Tukeys test. Average values were compared in the same line.

Across all four Zn levels, root dry weight varied from 0.05 to $0.90 \mathrm{~g} \cdot \mathrm{plant}^{-1}$, with an average value of 0.41 $\mathrm{g}$. plant ${ }^{-1}$. Black velvet bean produced the highest root dry weight at all four $\mathrm{Zn}$ levels. The root weight in diverse crop species is genetically controlled as well as influenced by environmental factors, especially by mineral nutrition [24]. Variation in root weight of cover crop species has been widely reported by Fageria [14] and Fageria and Moreira [25].

The increase in root dry weight was quadratic when Zn was applied in the range of 0 to $40 \mathrm{mg} \cdot \mathrm{kg}^{-1}$ (Table 5). Among the ten cover crop species, root dry weights of only four (smooth crotalaria, pueraria, lablab and gray velvet bean) increased significantly with increasing soil $\mathrm{Zn}$ levels. The rate of soil $\mathrm{Zn}$ for maximum root dry weight of these crops was $20 \mathrm{mg} \mathrm{Zn} \cdot \mathrm{kg}^{-1}$ for smooth crotalaria, $18 \mathrm{mg} \mathrm{Zn} \cdot \mathrm{kg}^{-1}$ for pueraria, $24 \mathrm{mg} \mathrm{Zn} \cdot \mathrm{kg}^{-1}$ for lablab and $20 \mathrm{mg} \mathrm{Zn} \cdot \mathrm{kg}^{-1}$ for velvet bean. The average $\mathrm{Zn}$ level for maximum root dry weight of the ten cover crops was $22 \mathrm{mg} \mathrm{Zn} \cdot \mathrm{kg}^{-1}$. Hence, it can be concluded that $\mathrm{Zn}$ requirements varied among the cover crop species. Fageria [24] and Fageria and Moreira [25] reported that root weight of crop plants increased in a quadratic fashion with the increasing levels of added Zn.

Maximum root length was significantly affected by $\mathrm{Zn}$ and cover crop treatments (Table 6). The Zn $\times$ cover crop interaction was also significant for maximum root length. Hence, it can be concluded that variation in maximum root length among cover crop species was not consistent across Zn rates. Maximum root length averaged across the four $\mathrm{Zn}$ levels varied from 9.75 for smooth crotalaria to $34 \mathrm{~cm}$ for black velvet bean, with an overall average of $24.5 \mathrm{~cm}$. It has been extensively reported that in Brazilian Oxisols, variation in maximum root length of cover crops was observed with the addition of different fertilizer rates [14] [24]. The increase in maximum root length was significant and quadratic for seven of the cover crop species as well as the average of the ten cover crop species (Table 7). The predicted $\mathrm{Zn}$ rate for maximum root length varied from $9 \mathrm{mg} \mathrm{Zn} \cdot \mathrm{kg}^{-1}$ for smooth crotalaria to $25 \mathrm{mg} \mathrm{Zn} \cdot \mathrm{kg}^{-1}$ for lablab, with an average value of $17 \mathrm{mg} \mathrm{Zn} \cdot \mathrm{kg}^{-1}$. Similar responses of 
Table 5. Relationship between soil Zn rate and root dry weight (RDW) of ten legume cover crops.

\begin{tabular}{lccc}
\hline \multicolumn{1}{c}{ Cover crops } & Regression equation & $\mathrm{R}^{2}$ & ZnRMRDW $^{1}$ \\
\hline Zn rate vs RDW of smooth crotalaria & $\mathrm{Y}=0.028+0.0037 \mathrm{X}-0.000091 \mathrm{X}^{2}$ & $0.80^{* *}$ & 20 \\
Zn rate vs RDW of pueraria & $\mathrm{Y}=0.039+0.0029 \mathrm{X}-0.000080 \mathrm{X}^{2}$ & $0.60^{*}$ & 18 \\
Zn rate vs RDW of lablab & $\mathrm{Y}=0.387+0.0213 \mathrm{X}-0.00044 \mathrm{X}^{2}$ & $0.50^{*}$ & 24 \\
Zn rate vs RDW of gray velvet bean & $\mathrm{Y}=0.453+0.0140 \mathrm{X}-0.00087 \mathrm{X}^{2}$ & $0.73^{* *}$ & 20 \\
Average of 10 cover crops & $\mathrm{Y}=0.240+0.0087 \mathrm{X}-0.00021 \mathrm{X}^{2}$ & $0.46^{*}$ & 22 \\
\hline
\end{tabular}

**** Significant at the 5 and $1 \%$ probability levels, respectively. ${ }^{1} \mathrm{ZnRMRDW}=\mathrm{Zn}$ rate for maximum root dry weight in $\mathrm{mg} \cdot \mathrm{kg}^{-1}$ soil.

Table 6. Influence of soil $\mathrm{Zn}$ on maximum root length (MRL, $\mathrm{cm} \cdot$ plant $^{-1}$ ) of ten tropical legume cover crops.

\begin{tabular}{|c|c|c|c|c|c|}
\hline \multirow{2}{*}{ Cover crops } & \multicolumn{4}{|c|}{ Zinc levels $\left(\mathrm{mg} \cdot \mathrm{kg}^{-1}\right.$ ) } & \multirow{2}{*}{ Average } \\
\hline & 0 & 10 & 20 & 40 & \\
\hline 1. Sunn hemp & $11.33 \mathrm{c}$ & $14.67 \mathrm{e}$ & $11.33 b$ & 8.66d & $11.50 \mathrm{~d}$ \\
\hline 2. Smooth crotalaria & $10.00 \mathrm{c}$ & $13.00 \mathrm{e}$ & $9.00 \mathrm{~b}$ & $7.00 \mathrm{~d}$ & $9.75 d$ \\
\hline 3. Showy crotalaria & $13.00 \mathrm{c}$ & $12.66 \mathrm{e}$ & $8.66 b$ & $7.00 \mathrm{~d}$ & $10.33 d$ \\
\hline 4. Calopo & $12.66 \mathrm{c}$ & $21.00 \mathrm{~d}$ & $9.00 \mathrm{~b}$ & 8.33d & $12.75 \mathrm{~d}$ \\
\hline 5. Pueraria & 8.33c & $13.66 \mathrm{e}$ & $15.33 b$ & $9.66 \mathrm{~d}$ & $11.75 d$ \\
\hline 6. Pigeonpea & $10.00 \mathrm{c}$ & $12.66 \mathrm{e}$ & $12.66 \mathrm{~b}$ & $8.00 \mathrm{~d}$ & $10.83 d$ \\
\hline 7. Lablab & $21.33 b$ & $30.66 \mathrm{bc}$ & $34.00 \mathrm{a}$ & 29.66ab & $28.91 b$ \\
\hline 8. Black velvet bean & 34.33a & 36.66ab & 34.33a & $31.00 \mathrm{a}$ & $34.08 \mathrm{a}$ \\
\hline 9. Gray velvet bean & $26.33 b$ & 39.33a & $33.66 a$ & $20.66 c$ & $30.00 \mathrm{~b}$ \\
\hline 10. Jack bean & $21.66 \mathrm{~b}$ & $25.66 \mathrm{~cd}$ & $26.33 a$ & $24.33 b c$ & $24.50 \mathrm{c}$ \\
\hline Average & $16.90 \mathrm{c}$ & $22.00 \mathrm{a}$ & $19.43 b$ & $15.43 \mathrm{c}$ & \\
\hline \multicolumn{6}{|l|}{ F-Test } \\
\hline Zn levels (Zn) & & & & & $* *$ \\
\hline Cover crops (C) & & & & & $* *$ \\
\hline $\mathrm{Zn} \times \mathrm{C}$ & & & & & $* *$ \\
\hline CV Zn (\%) & & & & & 14.84 \\
\hline CV C (\%) & & & & & 12.53 \\
\hline
\end{tabular}

${ }^{* * *}$ Significant at the $1 \%$ probability level. Means followed by the same letter in the same column are not statistically significant at the $5 \%$ probability level by Tukeys test. Average values were compared in the same line.

Table 7. Influence of soil $\mathrm{Zn}$ on maximum root length (MRL, $\mathrm{cm} \cdot$ plant $^{-1}$ ) of ten tropical legume cover crops.

\begin{tabular}{|c|c|c|c|}
\hline Variable & Regression equation & $\mathrm{R}^{2}$ & ZnRMRL $^{1}$ \\
\hline 1. $\mathrm{Zn}$ rate vs MRL of Sunn hemp & $Y=11.98+0.15 X-0.0061 X^{2}$ & $0.53^{*}$ & 13 \\
\hline 2. Zn rate vs MRL of smooth crotalaria & $Y=10.73+0.0732 X-0.0043 X^{2}$ & $0.53^{*}$ & 9 \\
\hline 5. $\mathrm{Zn}$ rate vs MRL of pueraria & $Y=8.38+0.6739 X-0.0161 X^{2}$ & $0.87^{* *}$ & 21 \\
\hline 6. Zn rate vs MRL of pigonpea & $Y=10.09+0.3287 X-0.0095 X^{2}$ & $0.61^{*}$ & 17 \\
\hline 7. Zn rate vs MRL of lablab & $Y=21.52+1.0837 X-0.0220 X^{2}$ & $0.61^{*}$ & 25 \\
\hline 9. Zn rate vs MRL of gray velvet bean & $\mathrm{Y}=28.82+1.0725 \mathrm{X}-0.0316 \mathrm{X}^{2}$ & $0.77^{* *}$ & 17 \\
\hline 10. Zn rate vs MRL of jack bean & $Y=21.84+0.4242 X-0.0091 X^{2}$ & $0.65^{* *}$ & 23 \\
\hline Average of 10 cover crops & $Y=17.55+0.3777 X-0.0109 X^{2}$ & $0.73^{* *}$ & 17 \\
\hline
\end{tabular}

${ }^{* *}$, NS Significant at the $1 \%$ probability level and not significant, respectively. ${ }^{1} \mathrm{ZnRMLW}=\mathrm{Zn}$ rate for maximum root length in mg. $\mathrm{kg}^{-1}$ soil. 
root length have been reported in crop plants with the addition of Zn in Brazilian Oxisol [14] [26]. Wang et al. [27] also reported that root growth is extremely sensitive to wide range of soil physical, chemical and biological factors, including mineral nutrition. Figure 2 shows root growth of cover crop species at different $\mathrm{Zn}$ levels. There were differences in root growth among cover crop species and also differences with the addition of different levels of $\mathrm{Zn}$ fertilizer.

\subsection{Zinc Concentration, Uptake and Use Efficiency}

Zn concentration (content per unit dry matter), Zn uptake (concentration $\times$ dry matter) and Zn use efficiency (dry weight per unit of Zn uptake) were significantly influenced by Zn level and cover crop (Tables 8-10). Overall, Zn concentration increased in a quadratic manner with the addition of $\mathrm{Zn}$ to the soil from 0 to 40 $\mathrm{mg} \cdot \mathrm{kg}^{-1}\left(\mathrm{Y}=18.23+6.14 \mathrm{X}-0.09 \mathrm{X}^{2}, \mathrm{R}^{2}=0.98^{* *}\right)$. The $\mathrm{Zn}$ concentrations in the cover crop shoots at various soil applied Zn levels were comparable to $\mathrm{Zn}$ concentrations reported for other legumes [28]. The Zn concentration of smooth crotalaria was always higher than the others and was two times higher than the average at the 40 $\mathrm{mg} \cdot \mathrm{kg}^{-1}$ level.

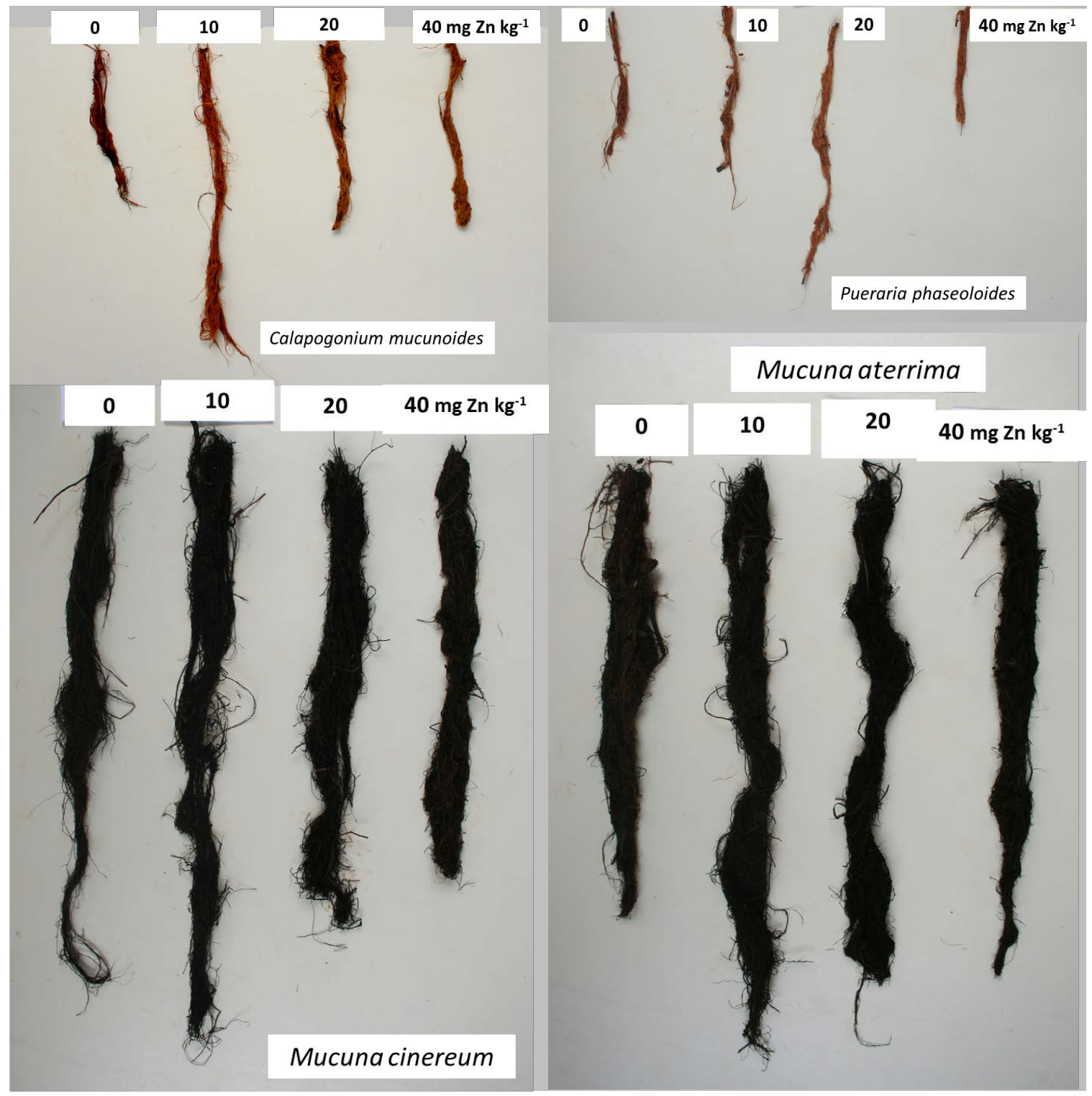

Figure 2. Root growth of selected cover crops at different soil Zn levels. 
Table 8. Influence of soil $\mathrm{Zn}$ on $\mathrm{Zn}$ concentration $\left(\mathrm{mg} \cdot \mathrm{kg}^{-1}\right)$ in the shoots of ten cover crops.

\begin{tabular}{|c|c|c|c|c|c|}
\hline \multirow{2}{*}{ Cover crops } & \multicolumn{4}{|c|}{ Zinc levels $\left(\mathrm{mg} \cdot \mathrm{kg}^{-1}\right)$} & \multirow{2}{*}{ Average } \\
\hline & 0 & 10 & 20 & 40 & \\
\hline 1. Sunn hemp & 15.86ab & $110.54 b$ & $118.08 b$ & $160.04 b$ & $101.13 \mathrm{~b}$ \\
\hline 2.Smooth crotalaria & $18.52 \mathrm{a}$ & 139.51a & 199.01a & $234.53 a$ & $147.89 \mathrm{a}$ \\
\hline 3. Showy crotalaria & 15.88ab & $136.74 a b$ & $176.24 a$ & $215.34 a$ & $136.05 \mathrm{a}$ \\
\hline 4. Calopo & 18.19a & 58.85cd & $60.62 \mathrm{e}$ & $65.12 \mathrm{e}$ & $50.69 \mathrm{e}$ \\
\hline 5. Pueraria & 14.62ab & $75.82 \mathrm{c}$ & 91.44bcd & $115.65 c$ & $74.38 \mathrm{c}$ \\
\hline 6. Pigeonpea & $18.27 \mathrm{a}$ & $64.97 \mathrm{~cd}$ & $98.84 \mathrm{bc}$ & 87.18cde & $67.32 \mathrm{~cd}$ \\
\hline 7. Lablab & $18.35 a$ & 59.35cd & 60.80de & $63.25 \mathrm{e}$ & $50.44 \mathrm{e}$ \\
\hline 8. Black velvet bean & 15.07ab & 51.33cde & 77.80cde & 75.12de & $54.83 e$ \\
\hline 9. Gray velvet bean & 15.06ab & 42.48de & 73.03cde & $109.57 \mathrm{~cd}$ & 60.03de \\
\hline 10. Jack bean & $11.05 b$ & $24.56 \mathrm{e}$ & $48.87 \mathrm{e}$ & $58.91 \mathrm{e}$ & $35.84 f$ \\
\hline Average & $16.08 \mathrm{~d}$ & $76.42 \mathrm{c}$ & $100.47 b$ & $118.47 \mathrm{a}$ & 77.86 \\
\hline \multicolumn{6}{|l|}{ F-Test } \\
\hline Zn levels (Zn) & & & & & $* *$ \\
\hline Cover crops (C) & & & & & $* *$ \\
\hline $\mathrm{Zn} \times \mathrm{C}$ & & & & & $* *$ \\
\hline CV Zn (\%) & & & & & 14.58 \\
\hline CV C (\%) & & & & & 11.74 \\
\hline
\end{tabular}

${ }^{* *}$ Significant at the $1 \%$ probability level. Means followed by the same letter in the same column are not statistically significant at the $5 \%$ probability level by Tukeys test. Average values were compared in the same line.

Table 9. Influence of soil $\mathrm{Zn}$ on $\mathrm{Zn}$ uptake $\left(\mathrm{mg} \cdot \mathrm{kg}^{-1}\right)$ in the shoots of ten cover crops.

\begin{tabular}{|c|c|c|c|c|c|}
\hline \multirow{2}{*}{ Cover crops } & \multicolumn{4}{|c|}{ Zinc levels $\left(\mathrm{mg} \cdot \mathrm{kg}^{-1}\right)$} & \multirow{2}{*}{ Average } \\
\hline & 0 & 10 & 20 & 40 & \\
\hline 1. Sunn hemp & $47.88 \mathrm{c}$ & 372.84a & $300.13 b c$ & 443.61ab & 291.12bc \\
\hline 2.Smooth crotalaria & $12.37 d$ & 149.09cd & $225.20 \mathrm{~cd}$ & $165.10 \mathrm{~cd}$ & $137.94 d$ \\
\hline 3. Showy crotalaria & 17.30d & $170.21 \mathrm{~cd}$ & $217.85 \mathrm{~cd}$ & $206.84 c$ & $153.05 \mathrm{~d}$ \\
\hline 4. Calopo & $7.10 \mathrm{~d}$ & $49.07 d$ & $48.07 d$ & $61.49 \mathrm{~d}$ & $41.43 \mathrm{e}$ \\
\hline 5. Pueraria & $8.32 d$ & $59.25 \mathrm{~d}$ & 77.29d & 86.74cd & $57.90 \mathrm{e}$ \\
\hline 6. Pigeonpea & $21.74 d$ & $103.80 \mathrm{~cd}$ & 201.91cd & $175.34 c d$ & $125.69 d$ \\
\hline 7. Lablab & 63.56bc & 461.01a & 485.60ab & $360.68 b$ & 342.71ab \\
\hline 8. Black velvet bean & 78.89ab & $330.04 \mathrm{ab}$ & $590.82 \mathrm{a}$ & 497.18a & 374.23a \\
\hline 9. Gray velvet bean & $45.80 \mathrm{c}$ & 325.91ab & 422.32ab & 201.33c & $248.84 c$ \\
\hline 10. Jack bean & $87.74 a$ & $229.45 b c$ & 487.63ab & 546.13a & 337.73ab \\
\hline Average & $39.07 \mathrm{c}$ & $225.06 b$ & $305.68 a$ & $274.44 a$ & 211.06 \\
\hline \multicolumn{6}{|l|}{ F-Test } \\
\hline Zn levels (Zn) & & & & & $* *$ \\
\hline Cover crops (C) & & & & & $* *$ \\
\hline $\mathrm{Zn} \times \mathrm{C}$ & & & & & $* *$ \\
\hline CV Zn (\%) & & & & & 25.84 \\
\hline CV C (\%) & & & & & 21.84 \\
\hline
\end{tabular}

${ }^{* *}$ Significant at the $1 \%$ probability level. Means followed by the same letter in the same column are not statistically significant at the $5 \%$ probability level by Tukeys test. Average values were compared in the same line. 
Table 10. Influence of soil $\mathrm{Zn}$ on $\mathrm{Zn}$ use efficiency $\left(\mathrm{mg} \cdot \mathrm{\mu g}^{-1}\right)$ in the shoots of ten cover crops.

\begin{tabular}{|c|c|c|c|c|c|}
\hline \multirow{2}{*}{ Cover crops } & \multicolumn{4}{|c|}{ Zinc levels $\left(\mathrm{mg} \cdot \mathrm{kg}^{-1}\right.$ ) } & \multirow{2}{*}{ Average } \\
\hline & 0 & 10 & 20 & 40 & \\
\hline 1. Sunn hemp & 63.10b & $9.23 \mathrm{c}$ & $8.47 \mathrm{~cd}$ & 6.27de & 22.69cde \\
\hline 2.Smooth crotalaria & $54.53 b$ & 7.17c & 5.03d & $4.26 \mathrm{e}$ & $18.25 \mathrm{e}$ \\
\hline 3. Showy crotalaria & 64.30b & 7.31c & $5.69 d$ & $4.64 \mathrm{e}$ & 20.39de \\
\hline 4. Calopo & $55.60 \mathrm{~b}$ & $17.20 \mathrm{bc}$ & 16.49ab & 15.47ab & 23.48bcde \\
\hline 5. Pueraria & 68.52ab & 13.22bc & 11.17bcd & 8.89cd & $27.10 \mathrm{bc}$ \\
\hline 6. Pigeonpea & $54.74 \mathrm{~b}$ & $15.44 \mathrm{bc}$ & $10.12 \mathrm{~cd}$ & $12.02 \mathrm{bc}$ & 22.30cde \\
\hline 7. Lablab & $54.61 \mathrm{~b}$ & $17.09 \mathrm{bc}$ & 16.53ab & 15.83ab & $25.06 \mathrm{bcd}$ \\
\hline 8. Black velvet bean & 70.17ab & $20.64 b$ & $13.26 \mathrm{bc}$ & 13.31ab & $29.97 b$ \\
\hline 9. Gray velvet bean & $66.95 \mathrm{ab}$ & $23.83 b$ & $14.08 \mathrm{bc}$ & 9.15cd & $29.54 b$ \\
\hline 10. Jack bean & $90.96 a$ & $41.96 \mathrm{a}$ & $21.11 \mathrm{a}$ & 17.09a & $40.80 \mathrm{a}$ \\
\hline Average & $64.35 a$ & $17.31 \mathrm{~b}$ & $12.19 \mathrm{c}$ & $10.69 \mathrm{c}$ & 26.14 \\
\hline \multicolumn{6}{|l|}{ F-Test } \\
\hline Zn levels (Zn) & & & & & $* *$ \\
\hline Cover crops (C) & & & & & $* *$ \\
\hline $\mathrm{Zn} \times \mathrm{C}$ & & & & & $* *$ \\
\hline CV Zn (\%) & & & & & 20.14 \\
\hline CV C (\%) & & & & & 19.11 \\
\hline
\end{tabular}

${ }^{* *}$ Significant at the $1 \%$ probability level. Means followed by the same letter in the same column are not statistically significant at the $5 \%$ probability level by Tukeys test. Average values were compared in the same line.

The average Zn uptake across four Zn levels varied from $41.43 \mu \mathrm{g} \cdot \mathrm{plant}^{-1}$ to $374 \mu \mathrm{g} \cdot$ plant $^{-1}$, with an average of $211 \mu \mathrm{g} \cdot$ plant $^{-1}$ (Table 9). Overall, Zn uptake varied from $39.07 \mu \mathrm{g} \cdot \mathrm{plant}^{-1}$ at the lowest $\mathrm{Zn}$ level to 305.68 $\mu \mathrm{g} \cdot$ plant $^{-1}$ at the $20 \mathrm{mg} \mathrm{Zn} \cdot \mathrm{kg}^{-1}$ soil. The uptake of $\mathrm{Zn}$ was quadratic and decreased at the highest $\mathrm{Zn}$ level $(\mathrm{Y}=$ $\left.50.89+28.57 \mathrm{X}-0.051 \mathrm{X}^{2}, \mathrm{R}^{2}=0.98^{* *}\right)$. The cover crop species showed differential uptake characteristics at given levels of soil Zn. Interspecific variation in Zn uptake has been reported for other legume crops [1] [18].

Zinc use efficiency varied from 18.25 to $40.80 \mathrm{mg} \cdot \mathrm{\mu g}^{-1}$, with an average value of $26.14 \mathrm{mg} \cdot \mathrm{ug}^{-1}$ across the four $\mathrm{Zn}$ levels (Table 10). The $\mathrm{Zn}$ use efficiency decreased with increasing soil $\mathrm{Zn}$ levels in a quadratic fashion $\left(\mathrm{Y}=58.58-4.36 \mathrm{X}+0.08 \mathrm{X}^{2}, \mathrm{R}^{2}=0.92^{* *}\right)$. The decrease in nutrient use efficiency with increasing soil nutrient levels is widely reported in the literature [12] [24]. The decrease in nutrient use efficiency at higher nutrient levels may be related to saturation of the plant's capacity for nutrient uptake [12] [14] [15]. Cover crops that have high Zn use efficiency might produce more yield when grown on Zn deficient soils. In the current study Jack bean, black velvet bean, pueraria and gray velvet bean had high $\mathrm{Zn}$ use efficiency at low and no application of Zn. Interspecific variation in nutrient use efficiency among tropical crops has been reported [16] [18] [19].

\section{Conclusion}

Cover crops are important components of cropping systems in maintaining sustainable crop production and soil quality. Results of this study show that Zn fertilization increased cover crop shoot dry weight, root dry weight and maximum root length; however response to applied Zn varied from species to species. Similarly, Zn concentration (content per unit dry weight), Zn uptake (concentration $\times$ dry weight) and $Z n$ use efficiency also varied from crop species to crop species. Hence, selection of suitable cover crops for $\mathrm{Zn}$ use efficiency is an important strategy in successful production of cover crops on Zn deficient soils. Overall, applied Zn rate needed for maximum dry weight of shoots and roots is about $22 \mathrm{mg} \mathrm{Zn} \cdot \mathrm{kg}^{-1}$ soil when the original level of the native soil is about $0.2 \mathrm{mg} \mathrm{Zn} \cdot \mathrm{kg}^{-1}$ determined by Mehlich 1 method. Among the ten cover crop species, jack bean, black velvet bean and lablab produced highest dry weight of shoots as well as roots. The cover crops which produced minimum dry weight of shoots and roots were calopo, pueraria, and smooth crotalaria. Jack bean, black velvet 
bean, and gray velvet bean had high Zn use efficiency at low soil Zn level and hence these cover crops might be suitable cover crops for soils with low available Zn.

\section{Acknowledgements}

We thank L. F. Stone for his excellent review and suggestions on the manuscript.

\section{References}

[1] Fageria, N.K., Baligar, V.C. and Clark, R.B. (2002) Micronutrients in Crop Production. Advances in Agronomy, 77, 185-268. http://dx.doi.org/10.1016/S0065-2113(02)77015-6

[2] Alloway, B.J. (2008) Micronutrients and Crop Production: An Introduction. In: Alloway, B.J., Ed., Micronutrient Deficiencies in Global Crop Production, Springer, New York, 1-39. http://dx.doi.org/10.1007/978-1-4020-6860-7 1

[3] Graham, R.D. (2008) Micronutrient Deficiencies in Crops and Their Global Significance. In: Alloway, B.J., Ed., Micronutrient Deficiencies in Global Crop Production, Springer, New York, 41-61. http://dx.doi.org/10.1007/978-1-4020-6860-7_2

[4] Fageria, N.K. and Stone, L.F. (2008) Micronutrient Deficiency Problems in South America. In: Alloway, B.J., Ed., Micronutrient Deficiencies in Global Crop Production, Springer, New York, 245-266. http://dx.doi.org/10.1007/978-1-4020-6860-7_10

[5] Singh, M.V. (2008) Micronutrient Deficiencies in Crop and Soils in India. In: Alloway, B.J., Ed., Micronutrient Deficiencies in Global Crop Production, Springer, New York, 93-125. http://dx.doi.org/10.1007/978-1-4020-6860-7 4

[6] Zou, C., Gao, X., Shi, R., Fan, X. and Zhang, F. (2008) Micronutrient Deficiencies in Crop Production in China. In: Alloway, B.J., Ed., Micronutrient Deficiencies in Global Crop Production, Springer, New York, 127-148. http://dx.doi.org/10.1007/978-1-4020-6860-7_5

[7] Cakmak, I. (2008) Zinc Deficiency in Wheat in Turkey. In: Alloway, B.J., Ed., Micronutrient Deficiencies in Global Crop Production, Springer, New York, 181-200. http://dx.doi.org/10.1007/978-1-4020-6860-7 7

[8] Sinclair, A.H. and Edwards, A.C. (2008) Micronutrient Deficiency Problems in Agricultural Crops in Europe. In: Alloway, B.J., Ed., Micronutrient Deficiencies in Global Crop Production, Springer, New York, 225-244. http://dx.doi.org/10.1007/978-1-4020-6860-7 9

[9] Brown, P.H. (2008) Micronutrient Use in Agriculture in the United States of America: Current Practices, Trends and Constraints. In: Alloway, B.J., Ed., Micronutrient Deficiencies in Global Crop Production, Springer, New York, 267286. http://dx.doi.org/10.1007/978-1-4020-6860-7_11

[10] Waals, J.H.V. and Laker, M.C. (2008) Micronutrient Deficiencies in Crops in Africa with Emphasis on Southern Africa. In: Alloway, B.J., Ed., Micronutrient Deficiencies in Global Crop Production, Springer, New York, 201-224. http://dx.doi.org/10.1007/978-1-4020-6860-7_8

[11] Fageria, N.K. and Baligar, V.C. (2008) Ameliorating Soil Acidity of Tropical Oxisols by Liming for Sustainable Crop Production. Advances in Agronomy, 99, 345-399. http://dx.doi.org/10.1016/S0065-2113(08)00407-0

[12] Fageria, N.K., Baligar, V.C. and Jones, C.A. (2011) Growth and Mineral Nutrition of Field Crops. 3rd Edition, CRC Press, Boca Raton.

[13] Fageria, N.K. and Baligar, V.C. (1997) Response of Common Bean, Upland Rice, Corn, Wheat, and Soybean to Soil Fertility of an Oxisol. Journal of Plant Nutrition, 20, 1279-1289. http://dx.doi.org/10.1080/01904169709365335

[14] Fageria, N.K. (2009) The Use of Nutrients in Crop Plants. CRC Press, Boca Raton.

[15] Fageria, N.K., Baligar, V.C. and Li, Y.C. (2008) The Role of Nutrient Efficient Plants in Improving Crop Yields in the Twenty First Century. Journal of Plant Nutrition, 31, 1121-1157. http://dx.doi.org/10.1080/01904160802116068

[16] Baligar, V.C. and Fageria, N.K. (2007) Agronomy and Physiology of Tropical Cover Crops. Journal of Plant Nutrition, 30, 1287-1339. http://dx.doi.org/10.1080/01904160701554997

[17] Fageria, N.K., Baligar, V.C. and Bailey, B.A. (2005) Role of Cover Crops in Improving Soil and Row Crop Productivity. Communications in Soil and Plant Analysis, 36, 2733-2757. http://dx.doi.org/10.1080/00103620500303939

[18] Baligar, V.C., Fageria, N.K., Paiva, A.Q., Silveira, A., Pomella, A.W.V. and Machado, R.C.R. (2006) Light Intensity Effects on Growth and Micronutrient Uptake by Tropical Legume Cover Crops. Journal of Plant Nutrition, 29, 19591974. http://dx.doi.org/10.1080/01904160600927633

[19] Baligar, V.C., Fageria, N.K., Paiva, A., Silveira, A., De Souza Jr., J.O., Lucena, E., Faria, J.C., Cabral, R., Pomella, A. W.V. and Jorda Jr., J. (2008) Light Intensity Effects on Growth and Nutrient-use Efficiency of Tropical Legume Cover Crops. In: Shibu, J. and Gordon, A., Eds., Toward Agroforestry Design: An Ecological Approach, Springer, Amsterdam, 67-79. http://dx.doi.org/10.1007/978-1-4020-6572-9_5 
[20] EMBRAPA (Empresa Brasileira de Pesquisa Agropecuária) (1997) Manual de Métodos de Análise de Solo (Manual for Methods of Soil Analysis). Centro Nacional de Pesquisa de Solos, Rio de Janeiro. www.agencia.cnptia.embrapa.br/Repositorio/Manual+de+Metodos

[21] Da Silva, F.C. (1999) Manual de Analyses Químicas de Solos, Plantas e Fertilizantes (Manual for Chemical Analysis of Soils, Plants and Fertilizers). EMBRAPA Informação Tecnológica, Brasilia.

[22] Fageria, N.K., Baligar, V.C. and Li, Y.C. (2009) Differential Soil Acidity Tolerance of Tropical Legume Cover Crops. Communications in Soil Science and Plant Analysis, 40, 1148-1160. http://dx.doi.org/10.1080/00103620902754127

[23] Lindsay, W.L. (1979) Chemical Equilibrium in Soils. John Wiley \& Sons, New York.

[24] Fageria, N.K. (2013) The Role of Plant Roots in Crop Production. CRC Press, Boca Raton.

[25] Fageria, N.K. and Moreira, A. (2011) The Role of Mineral Nutrition on Root Growth of Crop Plants. Advances in Agronomy, 110, 251-331. http://dx.doi.org/10.1016/B978-0-12-385531-2.00004-9

[26] Fageria, N.K. (2002) Micronutrients Influence on Root Growth of Upland Rice, Common Bean, Corn, Wheat, and Soybean. Journal of Plant Nutrition, 25, 613-622. http://dx.doi.org/10.1081/PLN-120003385

[27] Wang, H., Inukai, Y. and Yamauchi, A. (2006) Root Development and Nutrient Uptake. Critical Reviews in Plant Sciences, 25, 279-301. http://dx.doi.org/10.1080/07352680600709917

[28] Jones Jr., J.B., Wolf, B. and Mills, H.A. (1991) Plant Analysis Handbook. Micro-Macro Publishing, Inc., Athens. 